\title{
First record of Scybalocanthon nigriceps (Harold, 1868) (Coleoptera: Scarabaeidae: Scarabaeinae) in Rio Grande do Sul state, southern Brazil
}

\author{
SHEILA C. FERREIRA ${ }^{1}$, ROCCO A. DI MARE ${ }^{2}$ and PEDRO G. DA SILVA ${ }^{3}$ \\ ${ }^{1}$ Programa de Pós-Graduação em Biodiversidade Animal, Laboratório de Biologia Evolutiva, Universidade \\ Federal de Santa Maria, Av. Roraima, 1000, Camobi, 97105-900 Santa Maria, RS, Brazil \\ ${ }^{2}$ Centro de Ciências Naturais e Exatas, Departamento de Biologia, Universidade Federal de \\ Santa Maria, Av. Roraima, 1000, Camobi, 97105-900 Santa Maria, RS, Brazil \\ ${ }^{3}$ Programa de Pós-Graduação em Ecologia, Conservação e Manejo da Vida Silvestre, Instituto \\ de Biologia, Laboratório de Ecologia de Insetos, Universidade Federal de Minas Gerais, Av. \\ Presidente Antônio Carlos, 6627, Pampulha, 31270-910 Belo Horizonte, MG, Brazil \\ Manuscript received on March 8, 2017; accepted for publication on April 29, 2017
}

\begin{abstract}
The dung beetle, Scybalocanthon nigriceps (Harold, 1868), is recorded in Rio Grande do Sul state, Brazil, for the first time, at the Moreno Fortes Biological Reserve, municipality of Dois Irmãos das Missões, northwest region of the state, expanding the area of occurrence and distribution of this species in the country.
\end{abstract}

Key words: Atlantic Forest, dung beetle, new record, distribution expansion, southern Brazil.

\section{INTRODUCTION}

Dung beetles (Coleoptera: Scarabaeinae) represent a diverse group of insects globally distributed (over 6,200 species) that provide important ecosystem services (Nichols et al. 2008), which become a good model group to investigate applied ecological issues (Scholtz et al. 2009). Despite this, the lack of knowledge about the distribution of many species is still an important issue, especially in many regions of Brazil where there is a lack of studies on this fauna (Vaz-de-Mello 2000). The genus Scybalocanthon Martínez, 1948 (Coleoptera: Scarabaeinae) is a good example of that.

Correspondence to: Sheila Cassenote Ferreira

E-mail: cassenottesheila@gmail.com
Scybalocanthon is a genus of small-bodied dung beetles occurring in wet and dry forests of Central and South America (Martínez 1948, Pereira and Martínez 1956, Noriega et al. 2007, Molano-Rendón and Medina-Uribe 2010, Vaz-deMello et al. 2011). This genus was reviewed long ago by Pereira and Martínez (1956), and several authors have described new species recently (Molano-Rendón and Medina-Uribe 2010, Silva 2011, Molano-Rendón and Parrales 2015), now it comprises 19 described species (Molano-Rendón and Parrales 2015). It needs taxonomical revision since many uncommon and restricted species can not be securely identified at this moment (Vaz-deMello et al. 2014). Martínez and Halffter (1972) argued that species of this genus are diurnal, found during the hours of highest insolation, being 
good and agile fliers. Its species are attracted to mammal feces, carrion and fungi (Molano-Rendón and Medina-Uribe 2010). Despite the increasing number of studies on the subfamily Scarabaeinae, the information on distribution of Scybalocanthon species is still scarce.

One of its widespread species, Scybalocanthon nigriceps (Harold, 1868), has been recorded in Brazil, Bolivia and Paraguay (Forsyth et al. 1998, Spector and Ayzama 2003, Hamel-Leigue et al. 2006, Vaz-de-Mello et al. 2014). In Brazil, there are records from states of Paraná, São Paulo and Rio de Janeiro, a relatively widespread distribution across sites of Atlantic Forest (Schmidt 1922, Pessôa and Lane 1941, Hernández and Vaz-de-Mello 2009, Hernández et al. 2011, Vaz-de-Mello et al. 2014). It is a yellow-bodied diurnal species (Hernández 2002), occurring in shaded areas and commonly attracted to pitfall traps baited with human feces (Hernández and Vaz-de-Mello 2009, MolanoRendón and Medina-Uribe 2010). Messas et al. (2012) recorded a female of $S$. nigriceps removing portions of a carcass of the tree frog Haddadus binotatus (Spix, 1824) in São Paulo, arguing that this species has generalist trophic habits. In our study, $S$. nigriceps is reported for the first time from Rio Grande do Sul state, Brazil.

\section{MATERIALS AND METHODS}

Individuals of $S$. nigriceps were recorded in the Moreno Fortes Biological Reserve (27\%36'37'" S, 05330'05" W; Figure 1). It belongs to the physiographic region called Médio Alto Uruguai, municipality of Dois Irmãos das Missões, northwest region of the Rio Grande do Sul state, with an altitude ranging between 400 and $600 \mathrm{~m}$, and area of 474.8 ha. The Reserve is located in the Planalto das Missões region, with a Cfa climate (subtropical humid) according to the Köppen classification, rainfall average of $1600 \mathrm{~mm}$ per year, with April, May, June and October being the rainiest months.
The vegetation of the study area consists of two different types of forest, the Araucaria Forest (with predominance of Araucaria angustifolia (Bertol.) Kuntze) and the Deciduous Forest.

On July 15, 2016, Scarabaeinae specimens were collected in a pitfall trap $(1000 \mathrm{ml}$ plastic container with $11 \mathrm{~cm}$ diameter and $8 \mathrm{~cm}$ deep) buried with its edge at the ground level, filled with $250 \mathrm{ml}$ of water-detergent solution. Above the trap, a bait compartment (ca. $10 \mathrm{~g}$ of human feces) and a cover against rain were placed $48 \mathrm{~h}$ before. The specimens collected were transported to the Laboratory of Evolutionary Biology of the Universidade Federal de Santa Maria, where they were counted, separated, cleaned and sorted and then placed in small plastic containers with alcohol (70\%) and sent for expert identification. The permission to collect dung beetles was issued by Instituto Chico Mendes de Conservação da Biodiversidade (ICMBio) (SISBIO licence number \#54137-1).

The identification of $S$. nigriceps specimens was confirmed using the original and subsequent descriptions of the species (Harold 1868, Balthasar 1939) and dichotomous keys (Pereira and Martínez 1956, Vaz-de-Mello et al. 2011). We also made comparisons with new species descriptions (Molano-Rendón and Medina-Uribe 2010, Silva 2011, Molano-Rendón and Parrales 2015) and with specimens of $S$. nigriceps deposited at the Entomological Collection of the Universidade Federal de Santa Catarina, Florianópolis, southern Brazil, identified by an expert (Fernando Vaz-deMello, Universidade Federal de Mato Grosso).

\section{MATERIAL EXAMINED}

Brazil, Rio Grande do Sul: Dois Irmãos das Missões, ReBio Moreno Fortes, 27³6’31.79'S, 05330'03.52”'W, elev. $538 \mathrm{~m}, 15 / \mathrm{VII} / 2016$, Ferreira, S. C. and Di Mare, R. A. (2q); ibid, $27^{\circ} 36^{\prime} 31.79^{\prime} \mathrm{S}, 053^{\circ} 30^{\prime} 03.52^{\prime \prime} \mathrm{W}$, elev. $538 \mathrm{~m}$, 


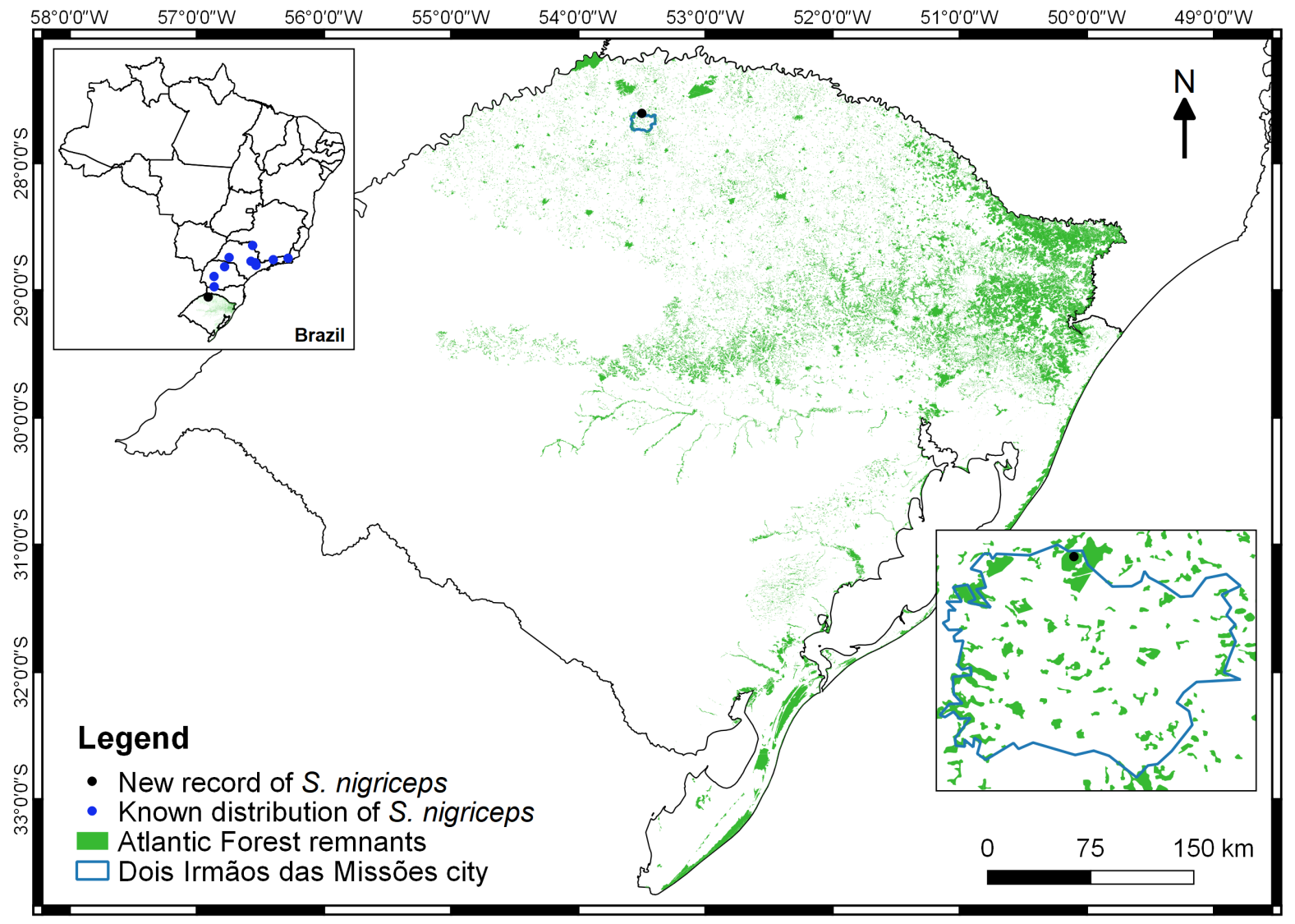

Figure 1 - Moreno Fortes Biological Reserve located in the municipality of Dois Irmãos das Missões, Rio Grande do Sul state, Brazil.

29/X/2016, Ferreira, S. C. and Di Mare, R. A. (1우). Individuals were deposited in the Entomological Collection of the Universidade Federal de Santa Catarina and Evolutionary Biology Laboratory of the Universidade Federal de Santa Maria, Rio Grande do Sul, Brazil.

Scybalocanthon nigriceps (Harold, 1868) (Figure 2)

Canthon nigriceps Harold, 1868. Berl. Entomol. Zeitschr. 12: 49.

Description of the species can be found elsewhere (Harold 1868, p. 49).

\section{TAXONOMIC COMMENTS}

The combinations of color patterns, especially in legs and elytra, only found in S. nigriceps compared to other species of the genus, allowed us to recognize its identity with certainty: pronotum and pygidium unicolored; elytra dark-brown and dark at the base and apex; legs bicolored, half yellow-browish (base), half dark-browish (appex) (Figure 2).

We conducted an extensive literature review to determine the known distribution of the species, and we found no records of $S$. nigriceps for the Rio Grande do Sul state. We also searched for records at the Global Biodiversity Information Facility (GBIF 2016) to found new and confirm previous records. Vaz-de-Mello et al. (2014) cited the states of Paraná, Rio de Janeiro and São Paulo, in Brazil, and southern Paraguay, as native region of this species. Hamel-Leigue et al. (2006) also cite Bolivia as country of occurrence of $S$. nigriceps. Therefore, we now extend the distribution of the species to the 
Rio Grande do Sul state, the southernmost point of its known distribution. The nearest site of its previous known distribution is located in the city of Pato Branco, Paraná state, about $182 \mathrm{~km}$ away from the new record of the species.

The state of Rio Grande do Sul has a relatively recent history of standardized field surveys of dung beetles, with a concentration of studies in the southern portion of the state (da Silva et al. 2008a, b, 2009, 2012a, b, 2013, Audino et al. 2011, da Silva 2011, da Silva and Audino 2011, da Silva and Di Mare 2012, Costa-Silva et al. 2014). To our knowledge, there is only one study performed, in a standardized way, in the northwest region of the Rio Grande do Sul (Lima et al. 2015). This site is located ca. $100 \mathrm{~km}$ south of the area sampled in the present study, with no record of $S$. nigriceps, even using a similar sampling protocol.

Scybalocanthon nigriceps is found in small patches of mid-temperate Atlantic Forest (Vaz-deMello et al. 2014), between 400 and 1000 m a.s.l., but there is a lack of detailed life history information of this species. However, there are records of it being attracted to pitfall traps baited with human feces (Hernández and Vaz-de-Mello 2009), rotten meat, rotten fish and pig dung (Korasaki et al. 2013). Messas et al. (2012) also recorded this species removing portions of a carcass of the tree frog Haddadus binotatus (Spix, 1824), supposedly to build its brood-balls. These observations suggest that this species has a generalist trophic habit or that it can use different resources for feeding and nesting. This is one of the demands to elucidate its biology.

This species is grouped as Least Concern in the International Union for Conservation of Nature Red List of Threatened Species (Vaz-de-Mello et al. 2014). Due to its widespread distribution, the main threat presumed for this species is the huge fragmentation and transformation of the Atlantic Forest to anthropogenic land uses (Ribeiro et al. 2009), which can impact the population size and,

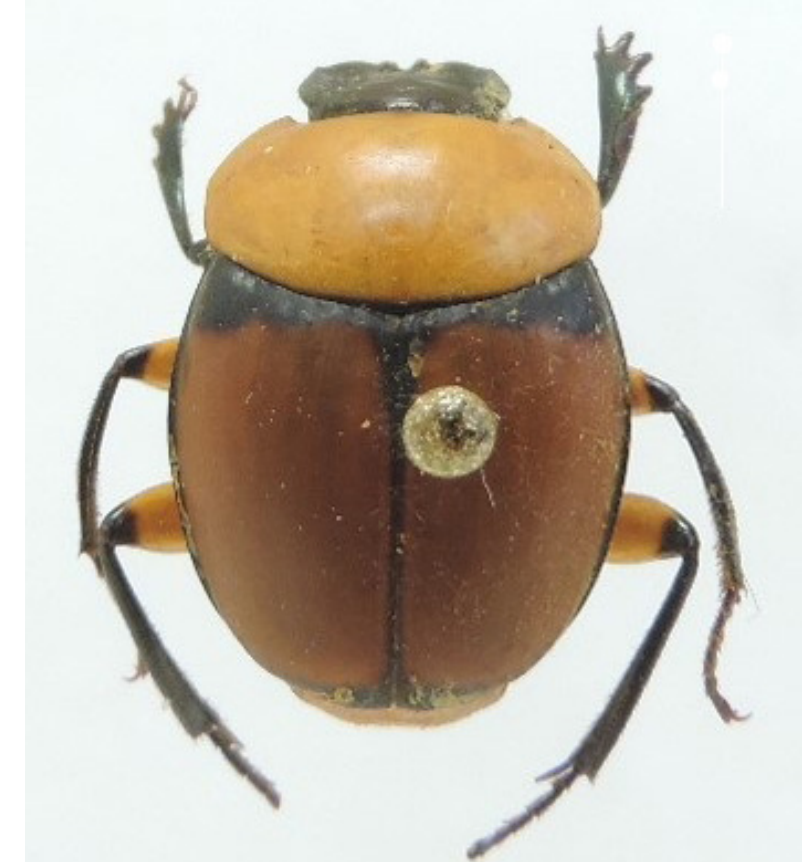

Figures 2 - Scybalocanthon nigriceps sampled in Moreno Fortes Biological Reserve. Scale bar $=2 \mathrm{~mm}$.

consequently, the long-term viability of $S$. nigriceps. This new record was found in a relatively small protected area (474.8 ha), compared to the other three forest fragments located to the northeast and northwest of the Moreno Fortes Biological Reserve, which could be a source area for this species. These fragments include the Turvo State Park, a protected area with $174.9 \mathrm{~km}^{2}$, which is part of a large forest mass that also extends through Argentina, and three Indigenous lands (Guarita, Nonoai and Rio da Várzea) grouped in two large fragments (see Figure 1). Therefore, based on the distribution map of the species in Brazil (Figure 1), and the record for Paraguay, we expect that $S$. nigriceps can be found in the state of Santa Catarina in Brazil and in northern Argentina (Misiones) with the realization of new studies on dung beetles.

\section{ACKNOWLEDGMENTS}

We would like to thank the Dois Irmãos das Missões City Hall and the Instituto Chico Mendes de Conservação da Biodiversidade (ICMBio) for permission to collect beetles. 


\section{REFERENCES}

AUDINO LD, DA SILVA PG, NOGUEIRA JM, MORAES LP AND VAZ-DE-MELLO FZ. 2011. Scarabaeinae (Coleoptera, Scarabaeidae) de um bosque de eucalipto introduzido em uma região originalmente campestre. Iheringia Ser Zool 101(1-2): 121-126.

BALTHASAR V. 1939. Eine Vorstudie zur Monographie der Gattung Canthon Hffsg. (10. Beitrag zur Kenntnis der Scarabaeiden der neotropischen Region.). Folia Zool Hydrobiol 9(2): 179-238.

COSTA-SILVA V, CIPOLATTO RP, ABEGG AD, ROSA CM, DA SILVA PG AND DI MARE RA. 2014. Escarabeídeos (Coleoptera: Scarabaeidae) de campo e floresta da Reserva Biológica de São Donato, Rio Grande do Sul, Brasil. Biotemas 27(4): 63-71.

DA SILVA PG. 2011. Dung beetles (Coleoptera: Scarabaeidae: Scarabaeinae) of two non-native habitats in Bagé, Rio Grande do Sul, Brazil. Zool Stud 50(5): 546-559.

DA SILVA PG AND AUDINO LD. 2011. Escarabeíneos (Coleoptera: Scarabaeidae) atraídos a diferentes iscas em campo nativo de Bagé, Rio Grande do Sul, Brasil. Rev Bras Zooc 13(1-2-3): 241-247.

DA SILVA PG, AUDINO LD, NOGUEIRA JM, MORAES LP AND VAZ-DE-MELLO FZ. 2012a. Escarabeíneos (Coleoptera: Scarabaeidae: Scarabaeinae) de uma área de campo nativo no bioma Pampa, Rio Grande do Sul, Brasil. Biota Neotrop 12(3): 246-253.

DA SILVAPG AND DI MARE RA. 2012. Escarabeíneos copronecrófagos (Coleoptera, Scarabaeidae, Scarabaeinae) de fragmentos de Mata Atlântica em Silveira Martins, Rio Grande do Sul, Brasil. Iheringia Ser Zool 102(2): 197-205.

DA SILVA PG, GARCIA MAR AND VIDAL MB. 2008a. Besouros copro-necrófagos (Coleoptera: Scarabaeidae stricto sensu) coletados em ecótono natural de campo e mata em Bagé, RS. CeN 30(2): 71-91.

DA SILVA PG, GARCIA MAR AND VIDAL MB. 2008 b. Espécies de besouros copro-necrófagos (Coleoptera: Scarabaeidae) da Região da Campanha do Rio Grande do Sul. Rev Cienc Agrovet 7(2): 143-149.

DA SILVA PG, GARCIA MAR AND VIDAL MB. 2009. Besouros copro-necrófagos (Coleoptera: Scarabaeidae sensu stricto) do município de Bagé, RS (Bioma Campos Sulinos). Biociencias 17(1): 33-43.

DA SILVA PG, VAZ-DE-MELLO FZ AND DI MARE RA. 2012b. Attractiveness of different baits to Scarabaeinae (Coleoptera: Scarabaeidae) in forest fragments in the extreme south of Brazil. Zool Stud 51(4): 429-441.

DA SILVA PG, VAZ-DE-MELLO FZ AND DI MARE RA. 2013. Diversity and seasonality of Scarabaeinae (Coleoptera: Scarabaeidae) in forest fragments in Santa Maria, Rio Grande do Sul, Brazil. An Acad Bras Cienc 85: 679-697.
FORSYTH AB, SPECTOR S, GILL B, GUERRA F AND AYZAMA S. 1998. Dung beetles (Coleoptera: Scarabaeidae: Scarabaeinae) of Parque Nacional Noel Kempff Mercado. In: Killeen TJ and Schulenberg TS (Eds), Rapid Assessment Program. A biological assessment of Parque nacional Noel Kempff Mercado, Bolivia. Conservation International, Washington, DC, p. 181-198.

GBIF- GLOBAL BIODIVERSITY INFORMATION FACILITY. 2016. Accessed at http://www.gbif.org/ species/1089173, February 2, 2017.

HAMEL-LEIGUE AC, MANN DJ, VAZ-DE-MELLO FZ AND HERZOG SK. 2006. Hacia un inventario de los escarabajos peloteros (Coleoptera: Scarabaeidae) de Bolivia: primera compilación de los géneros y especies registrados para el país. Rev Bol Ecol Cons Amb 20: 1-18.

HAROLD EV. 1868. Monographie der gattung Canthon. Berl Entomol Zeit 12: 1-144.

HERNÁNDEZ MIM. 2002. The night and day of dung beetles (Coleoptera, Scarabaeidae) in the Serra do Japi, Brazil: elytra colour related to daily activity. Rev Bras Entomol 46(4): 597-600.

HERNÁNDEZ MIM, MONTEIRO LR AND FAVILA ME. 2011. The role of body size and shape in understanding competitive interactions within a community of neotropical dung beetles. J Insect Sci 11: 13.

HERNÁNDEZ MIM AND VAZ-DE-MELLO FZ. 2009. Seasonal and spatial species richness variation of dung beetle (Coleoptera, Scarabaeidae s. str.) in the Atlantic Forest of southeastern Brazil. Rev Bras Entomol 53(4): 607-613.

KORASAKI V, LOPES J, BROWN GG AND LOUZADA J. 2013. Using dung beetles to evaluate the effects of urbanization on Atlantic Forest biodiversity. Insect Sci 20(3): 393-406.

LIMA JDN, COSTA SILVA V, BIANCHI V, DA SILVA PG AND DI MARE RA. 2015. Estrutura e organização de assembleias de Scarabaeinae (Coleoptera, Scarabaeidae) em diferentes fitofisionomias no sul do Brasil. Iheringia Ser Zool 105(4): 393-402.

MARTÍNEZ A. 1948. Insectos nuevos o poco conocidos - VI (Col. Scarabaeidae). Rev Soc Ent Arg 14(1-2): 3-11.

MARTÍNEZ A AND HALFFTER G. 1972. New taxa of American Canthonina (Coleoptera, Scarabaeinae). Entomol Arbeit Mus G Frey 23: 33-66.

MESSAS YF, SOUZA HS, SCHIFFLER G AND SOBCZAK JF. 2012. First record of necrophagy by Scybalocanthon nigriceps Harold(Coleoptera, Scarabaeidae, Scarabaeinae). Rev Bras Entomol 56(2): 257-258.

MOLANO-RENDÓN F AND MEDINA-URIBE CA. 2010. Especie nueva de Scybalocanthon (Coleoptera: Scarabaeinae: Canthonini) y descripción de la variación del órgano genital masculino. Rev Mex Biodiv 81: 689699. 
MOLANO-RENDÓN F AND PARRALES DA. 2015. Una nueva especie de Scybalocanthon Martínez 1948 (Coleoptera: Scarabaeinae) de los Andes colombianos. Bol Cient Cent Mus Univ Caldas 19(2): 359-368.

NICHOLS E, SPECTOR S, LOUZADA J, LARSEN T, AMEZQUITA S, FAVILA ME AND THE SCARABAEINAE RESEARCH NETWORK. 2008. Ecological functions and ecosystem services provided by Scarabaeinae dung beetles. Biol Conserv 141(6): 14611474.

NORIEGA JA, SOLIS C, ESCOBAR FS AND REALPE ER. 2007. Escarabajos coprófagos (Coleoptera: Scarabaeidae) de la provincia de la Sierra Nevada de Santa Marta. Biota Colomb 8(1): 77-86.

PEREIRA PFS AND MARTÍNEZ A. 1956. Os gêneros de Canthonini americanos (Col. Scarabaeidae). Rev Bras Entomol 6: 91-192.

PESSÔA SB AND LANE F. 1941. Coleópteros necrófagos de interesse médico-legal. Ensaio monográfico sobre a família Scarabaeidae de S. Paulo e regiões vizinhas. Arq Zool 2: 389-504.

RIBEIRO MC, METZGER JP, MARTENSEN AC, PONZONI FJ AND HIROTA MM. 2009. The Brazilian Atlantic Forest: How much is left, and how is the remaining forest distributed? Implications for conservation. Biol Conserv 142: 1141-1153.

SCHMIDT A. 1922. 1. Bestimmungstabelle der mir bekkanten Canthon-Arten. 2. Verbreintungsgebiete der Canthon-
Arten. 3. Neubeschreibungen von Canthon, Saprositis, Mendidius, Euparia und Ataenius. Arch Naturgesch 88(3): 67-103.

SCHOLTZ CH, DAVIS ALV AND KRYGER U. 2009. Evolutionary biology and conservation of dung beetles. Sofia: Pensoft Publishers, $567 \mathrm{p}$.

SILVA FAB. 2011. A new species of the genus Scybalocanthon (Coleoptera: Scarabaeinae) from Southeast Brazil. PLoS ONE 6(11): e27790.

SPECTOR S AND AYZAMA S. 2003. Rapid turnover and edge effects in dung beetle assemblages (Scarabaeidae) at a Bolivian Neotropical forest-savanna ecotone. Biotropica 35(3): 394-404.

VAZ-DE-MELLO F, LARSEN T, SILVA F, GILL B, SPECTOR S AND FAVILA M. 2014. Scybalocanthon nigriceps. The IUCN Red List of Threatened Species 2014: e.T138539A543339.

VAZ-DE-MELLO FZ. 2000. Estado atual de conhecimento dos Scarabaeidae s. str. (Coleoptera: Scarabaeoidea) do Brasil. In: Martín-Piera F, Morrone JJ and Melic A (Eds), Hacia un proyecto CYTED para el inventario y estimación de la diversidad entomológica en Iberoamérica: PrIBES-2000. Zaragoza: Sociedad Entomológica Aragonesa, p. 183-195.

VAZ-DE-MELLO FZ, EDMONDS WD, OCAMPO FC AND SCHOOLMEESTERS P. 2011. A multilingual key to the genera and subgenera of the subfamily Scarabaeinae of the New World (Coleoptera: Scarabaeidae). Zootaxa 2854: $1-73$. 